\title{
Habermas, Derrida and the Genre Distinction between Fiction and Argument
}

Sergeiy Sandler (sergeiys@gmail.com)

International Studies in Philosophy 39 (4), 2007, pp. 103- 119.

The Philosophical Discourse of Modernity, ${ }^{1}$ published by J ürgen Habermas in 1985, was very soon recognized as a major contribution to the ongoing cultural debate around postmodernism. ${ }^{2}$ Within this book, the "Excursus on Leveling the Genre Distinction between Philosophy and Literature" ${ }^{\prime 3}$ occupies a central position.

In what follows I will try to show that Habermas's critique of Derrida in the Excursus in fact turns upon itself (which is not to imply that I necessarily side with Derrida in the debate at large).

The Excursus polemically accuses J acques Derrida, as suggested in its title, of leveling the genre distinction between philosophy and literature. By trying to ignore this genre distinction, claims Habermas, Derrida is trying to pull through a "radical critique of reason" without getting caught in the "aporia of self-referentiality". ${ }^{4} \mathrm{He}$ explains:

There can only be talk about "contradiction" in the light of consistency requirements, which lose their authority or are at least subordinated to other demands - of an aesthetic nature, for example - if logic loses its conventional primacy over rhetoric. ${ }^{5}$

"Such discourses" - Habermas angrily notes in his concluding lecture in PDM "unsettle the institutionalized standards of fallibilism; they always allow for a final word, even when the argument is already lost: that the opponent has committed a category mistake in the sorts of responses he has been making". ${ }^{6}$

In the Excursus Habermas defends reason against this critique. Derrida's radical critique of reason, so Habermas explains, depends on his success in collapsing all genre distinctions, and especially those between philosophy, literature and literary criticism. However, Derrida's argument (as reconstructed by Habermas on pp. 190191 of the Excursus) is devastated by the counter-arguments brought by Habermas. Following the arguments brought against Derrida by Searle in the famous exchange between the two, Habermas has "defended the possibility of demarcating normal speech from derivative forms". ${ }^{7}$

${ }^{1}$ Jürgen Habermas, The Philosophical Discourse of Modernity: Twelve Lectures (Cambridge MA: MIT Press, 1987). I will hereafter refer to it as PDM. References to page numbers in the text are to PDM.

${ }^{2}$ See e.g. Christopher Norris, "Deconstruction, Postmodernism and Philosophy: Habermas on Derrida," in Habermas and the Unfinished Project of Modernity, ed. Maurizio Passerin D'Entrèves and Seyla Benhabib (Cambridge: Polity Press, 1996), 97- 123.

${ }^{3}$ PDM, 185-210. I will refer to it from now on briefly as the Excursus.

4 PDM, 190.

${ }^{5} \mathrm{PDM}, 188$.

${ }^{6}$ Ibid., 337. Cf. J acques Derrida, “White Mythology: Metaphor in the Text of Philosophy," in Margins of Philosophy, trans. Alan Bass (Brighton: The Harvester Press, 1982), 213: "Aristos (Ariste), the defender of metaphysics (a typographical error will have imprinted in the title Artiste), finishes by leaving, determined to break off dialog with a cheater: 'I leave unconvinced. If only you had reasoned by the rules, I could have rebutted your arguments quite easily"'. Derrida quotes here from The Garden of Epicurus, by Anatole France.

7 PDM, 199. 
Habermas then goes on to separate literature from philosophy, literary criticism and "the normal (everyday) use of language" ${ }^{8}$ by applying the Russian Formalist notion of dominant function of speech. Since the poetic function, although present in all uses of language, is dominant only in literature, claims Habermas, tools of literary criticism cannot be applied with equal success to all texts. In other discourses, like those of science, ethics, law and to some degree also philosophy, a central capacity of language is that of solving problems. Thus:

Derrida neglects the potential for negation inherent in the validity basis of action oriented towards reaching understanding; he permits the capacity to solve problems to disappear behind the world-creating capacity of language; the former capacity is possessed by language as the medium through which those acting communicatively get involved in relations to the world whenever they agree with one another about something in the objective world, in their common social world, or in the subjective worlds to which each has privileged access. ${ }^{9}$

Finally, on pp. 205-209, Habermas offers us his version of a 'Division of the Sciences', in which he arranges the language of literature on one hand, and "the specialized languages of science and technology, law and morality, economics, political science, etc.", ${ }^{10}$ on the other, in relation to ordinary language. Literary criticism and philosophy are presented by Habermas as mediating between the above-mentioned specialized areas and ordinary language. "11 "[I]n each of these enterprises," summarizes Habermas, "the tools of rhetoric are subordinated to the discipline of a distinct form of argumentation". ${ }^{12}$

$* * *$

Before I begin analyzing Habermas's argument, I would like to discuss an important matter of terminology.

As the title of the Excursus indicates (and as mentioned throughout the text), Habermas refers to the genre distinction between philosophy and literature. It seems probable that Habermas adopted the idea of using the term 'genre' in this context from Richard Rorty. Rorty's article "Philosophy as a Kind of Writing: An Essay on Derrida"13 indeed ascribes to Derrida the wish to describe philosophy as "[A] kind of writing. It is delimited, as any literary genre, not by form or matter, but by tradition".14

While Rorty tries to substantiate his use of the term 'genre' in this context, ${ }^{15}$ Habermas makes no reference in the Excursus to what he takes 'genre' to mean. At

\footnotetext{
8 Ibid.

9 PDM, 205.

10 PDM, 209.

${ }^{11}$ The claim that literature is more in need of such mediation to reach ordinary language than literary criticism or philosophy is, at least on the face of it, patently false, as can be shown on the example of any bestseller.

12 PDM, 209- 210.

${ }^{13}$ Richard Rorty, "Philosophy as a Kind of Writing: An Essay on Derrida," in Consequences of Pragmatism, (Minneapolis: University of Minnesota Press, 1982), 90- 109.

14 Ibid., 92.

${ }^{15}$ He claims that the tradition of "talk about Plato, Augustine, Descartes, Kant, Hegel, Frege, Russell .... and that lot" (ibid., 92) constitutes such a genre, namely that of philosophy. Although I find the claim that genres are traditions to be essentially true, I do not think this kind of tradition can qualify as literary genre. This is, however, a discussion that does not belong in the present work.
} 
best, we can take his discussion of the functions of language and of speech act theory to imply that he views a genre as a group of texts or utterances sharing the same dominant function or illocutionary act.

Now this is rather unfortunate, because the application of the term 'genre' to such categories as philosophy and literature is far from obvious. Philosophy, for instance, is very diverse in terms of both form and content. Philosophy comes not only in the form of academic papers and treatises, but also in epic poetry (e.g. Parmenides), lyric poetry (some of Nietzsche's work), dialogs (Plato, Hume, Ockham and many others), pseudo-mathematical treatises (Spinoza), soliloquies (St. Augustine, Descartes), scholastic quæestiones and many other forms too. It also deals with a very broad variety of subjects, almost all of which are not exclusive to philosophy, and often shared by sciences, arts and, of course, literature. Even Rorty's criterion - talk about other philosophers - is not exclusive to philosophy on one hand and is missing in many distinctly philosophical works on the other.

It would take much more than what Habermas offers us in the Excursus to substantiate the claim that philosophy is, in any reasonable sense of the word, a genre. It would be even more difficult to show that philosophy, making use of so many distinctly literary forms (like epic and lyric poetry, for instance), is a genre clearly distinct from literature.

It is true that literary theory so far failed to come up with any agreed definition of genre. ${ }^{16}$ Some theorists tried to develop conceptions of genre that would contain even such diverse entities as the whole of literature. ${ }^{17}$ Still, Habermas offers us no such developed conception, while the theories to which he refers make no room for any sharp genre distinction between philosophy and literature.

This can be illustrated on the example of Plato. The same dialogs that are considered to be the best extant Greek prose have also earned their author the title Prince of Philosophers. How are we to decide which function of language is dominant in Plato's dialogs? Should we claim that the poetical world-making function is dominant there, or should we declare that this function is only secondary there, and that the dialogs are oriented toward solving problems?

As far as speech act theory is concerned, the dialogs seem to make what Habermas believes to be deviant use of language. An illocutionary act represented in one of the dialogs is not supposed to have real binding force. So are we to classify the dialogs as literature and not as philosophy? But if Plato's dialogs are not philosophy - what is? So maybe we should disqualify what are clearly works of fiction, and canonical ones too, from counting as literature?

The point I am trying to make is that the genre distinction Habermas is talking about is not a distinction between philosophy and literature. Habermas himself often uses the term 'fiction' as synonymous with literature', while 'discursive', 'argumentative' and at one point 'scholarly' (p. 189) are used interchangeably with 'philosophical'. The implied claim that literature is somehow identical with fiction is dubious. ${ }^{18}$ The claim that philosophy is always argumentative and scholarly is, as we

\footnotetext{
${ }^{16}$ As acknowledged, e.g. by Ralph Cohen, "History and Genre," New Literary History, 17, no. 2 (1986): 203- 204.

${ }^{17}$ See e.g. Alastair Fowler, Kinds of Literature (Oxford: Clarendon Press, 1982), 1- 19. Note however that Fowler is willing to consider philosophy as part of literature, following several renaissance critics like Minturno (see pp. 9 and 11).

${ }^{18} \mathrm{Cf}$. ibid., 17: 'If a work fails to get in [i.e. be counted as literature] as 'fictional discourse', it can always try again as 'the best that is thought or said'". See also Fowler's critical discussion of the attempt to create a definition of literature on the basis of speech-act theory on pp. 6- 8.
} 
just saw, plainly false.

But perhaps there is a way to make this claim somewhat better. Thomas McCarthy, in his introduction to PDM, claims that what is "philosophical in any emphatic sense of the term" is "logical rather than literary, literal rather than figurative". ${ }^{19}$ Perhaps what Habermas means to imply is that even within those philosophical texts that are fictional there is a logical', literal', 'argumentative' element or part, which alone is "emphatically philosophical". In my opinion, it is precisely this view that provides much of the motivation behind Derrida's philosophical endeavors.

$* * *$

It has been claimed by several authors that Habermas incorrectly interprets Derrida's work. ${ }^{20}$ In the words of J ay Bernstein, in the Excursus: "Habermas defends a thesis, viz., that from the perspective of ordinary usage the genre distinction between philosophy and literature cannot be leveled, that, so far as I am aware, Derrida never denies". ${ }^{21}$

In fact, Habermas does not seem to care too much about whether or not he is faithful in reconstructing Derrida's philosophy. Throughout the Excursus no reference is made to any of Derrida's works (although many statements are made in Derrida's name). The one exception is footnote 7, where Habermas lists the texts constituting the famous Derrida-Searle exchange. However, in recounting the main points of this exchange, Habermas relies on J onathan Culler.

Habermas's own explanation for this strange omission of Derrida's writings from a polemic against Derrida goes like this:

Since Derrida does not belong to those philosophers who like to argue, it is expedient to take a closer look at his disciples in literary criticism within the Anglo-Saxon climate of argument. $^{22}$

Thus, Habermas is keen to obtain an argument to which Derrida's work can be reduced. He ignores as accidental the fact that "Derrida does not belong to those philosophers who like to argue," and turns to the Anglo-Saxon disciples for arguments to represent Derrida. ${ }^{23} \mathrm{He}$ fails (or maybe does not wish) to take into account the possibility that there is a philosophical rationale behind Derrida's unwillingness to argue. This attitude is sharply exhibited in the following quote, occupying a strategic location within the Excursus:

This - at first glance inconspicuous - transformation of the "destruction" to the

"deconstruction" of the philosophical tradition transposes the radical critique of reason

${ }^{19}$ PDM, xii.

${ }^{20}$ See Norris, "Deconstruction, Postmodernism and Philosophy," as well as his article "Derrida on the Isles," Belgrade Circle J ournal 0 (1994), http://www.usm.maine.edu/ bcj/ issues/one/norris.html. See also J ay M. Bernstein, "The Causality of Fate: Modernity and Modernism in Habermas," in Habermas and the Unfinished Project of Modernity, 245- 268.

${ }^{21}$ Ibid., 249.

22 PDM, 193.

${ }^{23}$ Some distinguished commentators, notably Christopher Norris and Rodolphe Gasché, would consider such a move much less than "expedient," claiming that those disciples misunderstand Derrida. Indeed, the very fact that they, so to say, put arguments in Derrida's mouth speaks against them. See Norris, "Derrida on the Isles," as well as his book Derrida (Cambridge, MA: Harvard University Press, 1987). See Also Rodolphe Gasché, Inventions of Difference: On J acques Derrida (Cambridge, MA: Harvard University Press, 1994). 
into the domain of rhetoric and thereby shows it a way out of the aporia of selfreferentiality: Anyone who still wanted to attribute paradoxes to the critique of metaphysics after this transformation would have misunderstood it in a scientistic manner. This argument holds good only if the following propositions are true... ${ }^{24}$

The contrast between the last sentence and the rest of the quote is striking. Habermas seems determined to reduce Derrida's work to a set of logical arguments by all means. Of course, once he does so, he not only misunderstands Derrida "in a scientistic manner," but also presupposes Derrida's failure. Any argument against Derrida based on such a reduction is simply circular.

$* * *$

To frustrate efforts at such an argumentative reduction is a key element in Derrida's philosophical project. It is possible to present Derrida's work as an attempt to establish an alternative, non-argumentative, way of doing philosophy. ${ }^{25}$ To write in a non-argumentative way is one necessary element of this overall project. It is, however, far from sufficient.

Many philosophers in the past, as we have seen, chose non-argumentative forms of writing, but within the presently dominant argumentative tradition of philosophy, their work has been reduced to a set of arguments. To use the example of Plato's dialogs again, it has become traditionally accepted already in late antiquity to view certain characters of the dialogs (usually Socrates) as simple mouthpieces for Plato. The fact that Plato chose to write dialogs rather than lectures is often ignored, sometimes explained away and on rare occasions used to explain away some obvious shortcoming of an argumentative interpretation of Plato. The other characters of the dialogs are recalled to excuse clearly fallacious reasoning on the part of the leading character. The wonderfully comical and humorous nature of most dialogs is also discarded and only reappears as 'Socratic irony' when the argument derived from the text clearly contradicts the line of argument traditionally viewed as 'Platonic'. ${ }^{26}$

The argumentative genre of writing philosophy is more than just a style. It has behind it an entire conception of how philosophy is to be written and read. When presenting an alternative to this genre, Derrida has to present also a complete alternative meta-philosophy, one that would be suggested to us without being explicitly claimed or argued for.

Within this meta-philosophy Derrida must counter the reinterpretation of nonargumentative works into arguments. He must not only inhibit such attempts to appropriate his own work, but also exhibit the possibility of reinterpreting distinctly argumentative works as non-argumentative literary constructs. ${ }^{27}$ This attempt has been taken by many (including Habermas) to be the essence of deconstruction. ${ }^{28}$

24 PDM, 190; italics added.

${ }^{25}$ To properly substantiate such a claim would of course require a very extensive study. Here I only offer a few remarks to make such an interpretation plausible.

${ }^{26}$ An intriguing work on Plato, both exposing some of these shortcomings of the standard philosophical interpretation, and offering some interesting alternatives is J ames A. Arieti, Interpreting Plato: The Dialogs as Drama (Lanham, MD: Rowman \& Littlefield, 1991).

${ }^{27}$ Cf. David Couzens Hoy, "Splitting the Difference: Habermas's Critique of Derrida," in Habermas and the Unfinished Project of Modernity, 132: "[D]econstruction may appear to have the status of philosophy because it claims universal applicability. There is no form of text, no genre of discourse, nothing that can be said, thought or done that escapes its purview".

${ }^{28}$ Here is how Habermas refers to this process in the Excursus (p. 189): "Derrida proceeds by a critique of style, in that he finds something like indirect communications, by which the text itself 
To create such an alternative mode of doing philosophy, Derrida must use a complex hybrid form of writing. Habermas is correct in pointing to Derrida's attempt to unite literature and literary criticism (p. $190 \mathrm{ff}$.) Derrida needs a form of writing, which will be literary ${ }^{29}$ on one hand, but with the capability to reflect on itself and on other works on the other.

This requires the use of some stylistic and compositional devices. One such device is parody. ${ }^{30}$ Other such devices are listed by David Wood, ${ }^{31}$ who rightly notes the intimate connection between style and strategy in Derrida's work. It is however a mistake that wood makes that will allow us to better examine the workings of Derrida's writing.

Like Habermas, David Wood also reads Derrida as offering a radical critique of reason. ${ }^{32}$ One reason he does so is that he understands some of the things Derrida writes to be said in full earnest. ${ }^{33}$ He then points out the incompatibility of speaking in full earnest with Derrida's philosophical project.

$$
\text { *** }
$$

To see what is wrong with Wood's reading of Derrida, let us examine one of those quotes that are commonly used in accounts of Derrida's work to indicate his real position. This one is usually brought to show Derrida's subversive intentions. It is also used in this capacity by Habermas (pp. 182, 406). The quote originally comes from the lecture "Différance," ${ }^{\prime 34}$ and I shall now examine it within the context of that lecture.

Note 43 to the seventh lecture in PDM (the lecture on Derrida, immediately preceding the Excursus) goes like this:

About "differance" Derrida states: "It governs nothing, reigns over nothing, and nowhere exercises any authority. It is not announced by a capital letter. Not only is there no

denies its manifest content, in the rhetorical surplus of meaning inherent in the literary strata of texts that present themselves as non-literary ... Thanks to their rhetorical content, texts combed against the grain contradict what they state".

${ }^{29}$ Again, indicating what precisely is meant by literary' in this context and showing how it applies to Derrida's writings goes well beyond the possible limits of this paper.

${ }^{30}$ Here is an example from Derrida's "Envois," in The Post Card, trans. Alan Bass (Chicago: University of Chicago Press, 1987), 99: "The author of the book of which I am speaking, himself, not his name (therefore he would pardon me for not naming him) is himself reserved as concerns the very interesting 'position of Quine' ('a word-between-quotation-marks is the proper name of the word which figures between the quotation marks, simultaneously an occurrence of the word which is between the quotation marks and an occurrence of the word-between-the-quotation-marks, the latter including the former as a part' - and it is true that this logic of inclusion perhaps is not very satisfying in order to account for the 'simultaneously', but small matter here), and making an allusion to a 'forgetting', his word, a forgetting 'evidently facilitated by the resemblance that there is between a word and the name of this word formed by its being placed between quotation marks', he concludes, I quote, 'But one must not let oneself be abused by this resemblance, and confuse the two names ...' Okay, promise, we won't any more. Not on purpose anyway. Unless we forget, but we will not forget on purpose, it's just that they resemble each other so much". This passage is also quoted in Norris, "Deconstruction, Postmodernism, Philosophy," 108- 109.

${ }^{31}$ David Wood, "Style and Strategy at the Limits of Philosophy: Heidegger and Derrida," The Monist 63, no. 4 (1980): 494- 511. See especially pp. 505- 507.

32 Ibid., 495 and passim.

33 Ibid., 506; he refers there to passages in which Derrida seems to explain his own way of proceeding.

${ }^{34}$ J acques Derrida, “Différance," in Margins of Philosophy, 3- 27. 
kingdom of differance, but differance instigates the subversion of every kingdom”35

Let us start at the proper beginning. Let us begin with the capital letter. "It [différance] is not announced by any capital letter," and let me stress, any capital letter. I refer here not only to the capital D of "Différance" (the title of the article, literally announcing différance), but also to the capital A, to which refer the first sentences of the article. The pyramid-like form of this letter is discussed already on the second page of the article ${ }^{36}$ and again, within the same context as our quote, and only one page later. ${ }^{37}$ It is true that the capital letter in our quote is used in a metaphoric sense, but if Derrida wanted to make a simple statement there, one that is not counteracted in any way within the text, he would have selected another metaphor.

Yet another thing to note is the nature of the subject of all the sentences in our quote - différance. As Derrida says, "différance is literally neither a word nor a concept". ${ }^{38}$ This deliberately enigmatic expression can and should be interpreted in many different ways and directions (Derrida, of course, provides no gloss on his own expression here). ${ }^{39}$ I would like to dwell on one of them, which is relevant to the point I am trying to make.

A concept (and I am now referring to 'concept' as more or less synonymous with 'term') differs from a mere word in several ways. In one sense, a concept is simply a word or expression identified specifically with a particular branch of culture, with a particular author, subject, etc. In another sense, a concept differs from a word by virtue of being precise and unequivocal.

Words might have more than one meaning. More important, they always mean somewhat different things when used in different contexts. There might also be an ambiguity as to the precise signification of a word in a given sentence and text. This feature of words is perceived as problematic throughout the argumentative tradition in philosophy. ${ }^{40}$

The concept comes to redress this unfortunate state of affairs. A concept (at least in principle) is supposed to have a definition. The definition constructs a single sense of the concept, delimits it from all other possible meanings and allows using it in the relevant argumentative discourse without fear of misunderstanding and ambiguity. Precision and lack of ambiguity are the argumentative virtues par excellence.

One sense in which many 'terms' used by Derrida are neither words nor concepts is that they are distinctly linked with particular discourses and texts, but this link is attained by other means than in the case of concepts. Such words as différance receive their distinct connection with a particular discourse by virtue of expanding their possible range of meaning. The use of such terms not only allows Derrida to say many different things at the same time. It also allows him to say precisely nothing (or say nothing precisely). He can convey a great richness of possible meanings to his

\footnotetext{
${ }^{35} \mathrm{PDM}, 406$. The note is to p. 182 of PDM. The quote from Derrida is from p. 22 in the article "Différance".

${ }^{36}$ Derrida, "Différance," 4; footnote 2 by the translator addresses this issue explicitly.

37 Ibid., 23.

38 Ibid., 3.

${ }^{39}$ See Gasché, Inventions of Difference, 5 ff. for an account of an argument between Gasché and Rorty on the application of this phrase to the study of Derrida's work.

${ }^{40}$ An issue treated at length by Derrida in "White Mythology," especially in connection with Aristotle and the Topics ("White Mythology," $247 \mathrm{ff}$.) Note that for Aristotle himself the virtue of precision and lack of ambiguity is linked with the use of proper names in a dialectic debate.
} 
readers without making any claim in particular. The readers are left with the task (akin to that performed in literary analysis) of revealing to themselves those potential meanings. Derrida can thus say (in the sense of conveying meanings) without saying (in the sense of making propositional claims).

Différance is usually presented briefly as a combination of difference and deferral, but this description is far from sufficient. It does preserve the essential point, though - this term, distinctly associated with Derrida, is no concept. Already the coupling of 'difference' and 'deferral' in one word indicates expansion, rather than narrowing, of meaning. However, this expansion of meaning goes not nearly far enough. The whole lecture, with all its allusions and references to other texts and cultural phenomena, is an exposition (inside-out definition) for the meaning of différance. And Derrida shows us that this meaning can be expanded further indefinitely.

The lecture begins in medias res ("I will speak, therefore, of a letter"). This beginning implies that we missed something at the beginning, that the beginning of the article is not the real beginning and something preceded it, giving an explanation and a context for the whole discourse. It also implies that the lecture is incomplete, that it only provides a partial explanation of what différance is, that this 'definition' of différance is incomplete, open-ended, indefinite. The full exposition, if it were possible to create one, would cover all our culture, every text, every subject, every interpretation. It would have to be redrawn from the start at every moment, with every new word.

The end of the article, on the other hand, questions the very legitimacy of writing this article:

Such is the question: the alliance of speech and Being in the unique word, in the finally proper name. And such is the question inscribed in the simulated affirmation of différance. It bears (on) each member of this sentence: "Being / speaks / always and everywhere / throughout/ language". ${ }^{41}$

The last sentence comes from Heidegger's article "The Anaximander Fragment". The one paragraph before last connects it with the hope ascribed to Heidegger of finding "the first word of Being”. The word différance (which is "'Older' than Being itself $^{\prime 42}$ ) applies (in a sense) for this vacancy in the very article we are reading (this is one way to understand "the simulated affirmation of différance"). Since it is 'older' than Being itself, it is in fact overqualified for this job.

These considerations are already sufficient to undermine any 'innocent' reading of the quote examined in this section. Its 'direct' or 'immediate' meaning (whatever it may be) is already seen to be a player in a complex game. If an interpretation of the whole text will eventually find this sentence to reflect the earnest position of the (implied) author, it will only do so after taking into account many distinctly literary' elements and integrating them into a literary interpretation of the text.

In a sense, any affirmation Derrida makes can be described as a "simulated affirmation". Never does he neglect to counteract, complete, qualify (overqualify, disqualify) and diversify the meaning of such 'affirmations'. The act of affirmation itself, in Derrida's texts, is indeed only simulated. What he thus 'affirms' cannot be taken to be his final word, said in full earnest.

$* * *$

Habermas is thus too eager to ascribe to Derrida a totalizing critique of reason and

${ }^{41}$ Derrida, "Différance," 27; italics added.

42 Ibid., 26. 
the desire to collapse all genre distinctions. He accepts too soon some sentences taken somewhat out of context in Derrida's texts at face value. He believes too naively that what Derrida's (self-declared) American disciples say in an argumentative way is simply equivalent to what Derrida (who does not "like to argue") writes in a non-argumentative way. That preventing the possibility of such a simple equivalence is one of Derrida's main tasks is simply ignored. The result is an uncharitable reading of Derrida - a failure by argumentative standards. ${ }^{43}$

In the careful attention that Derrida pays to the differences and incompatibilities between fiction and argument he shows that he is very conscious of this genre distinction. He works with it even as he is mixing the two genres. ${ }^{44}$ Derrida writes in a way that tries to destabilize the (already blurred) border line between fictional and argumentative writing. But this is not the same as leveling the genre distinction between the two. Like his distinctive terms, Derrida's writing is inclusive. It does not try to subordinate argument to fiction or fiction to argument. Rather, Derrida responds to both traditions. It is essential to his philosophical project that the voices (to borrow a term from Mikhail Bakhtin) of both the literary tradition and the argumentative tradition be heard within the unity of his work. A blending of these distinct voices into one would have meant the failure of his attempt to challenge the established division between the two genres.

What bothers Habermas in Derrida's work is not the leveling of the genre distinction, but rather Derrida's challenge to a hierarchy of genres, ${ }^{45}$ or, more precisely, his challenge to the exclusivity of the argumentative genre in philosophy and in public discourse.

To illustrate this point I would like to examine in brief an article by Karl-Otto Apel, called "Openly Strategic Uses of Language: A Transcendental-Pragmatic Perspective (A second attempt to think with Habermas against Habermas)". ${ }^{46}$ As the subtitle indicates, this article offers a friendly critique of Habermas and his theory of communicative action. In particular, Apel sympathizes with Habermas's idea that uses of language oriented toward unconstrained mutual understanding are the most basic uses of language, upon which all other uses are parasitic. However, Apel believes Habermas is trying to demonstrate this point in an inefficient manner. Habermas proceeds by way of "a formal pragmatics, which ultimately aims to demonstrate the presuppositions of language use in an empirical-descriptive manner"- a way by which "it is impossible to decide whether there is a fundamental

\footnotetext{
${ }^{43}$ The principle of charity states that one should interpret texts so that they would yield the strongest possible argument. It is a maxim of interpretation strictly internal to the argumentative tradition.

${ }^{44}$ In this respect it would be interesting to note Derrida's lecture "The Law of Genre," in Acts of Literature, ed. Derek Attridge (New York: Routledge, 1992), 221- 252. A typical misunderstanding of Derrida's work would view this piece as a declared rejection of the concept of genre. In fact, Derrida explores in that lecture the possibility of genres being essentially unstable ("mad"). Such instability may have devastating effects on the concept of genre if it is taken with the full baggage of genus in the sense this term has in traditional Aristotelian logic (as every French speaker, Derrida is well aware of that meaning, of course). But it is simply wrong to ascribe to him the negation of genre as such. He works with the category of genre in that very lecture. Moreover, it is possible to develop generic instability itself into a Derrida-inspired form of genre theory - for an example of such development see Thomas O. Beebee, The Ideology of Genre: A Comparative Study of Generic Instability, (University Park: Pennsylvania State University Press, 1994).

${ }^{45}$ Note Habermas's insistence, following Searle, to view some uses of language, like quoting, playing out or using metaphorical senses of words, as deviant, as opposed to the normal serious and literal use (PDM, $196 \mathrm{ff})$.

${ }^{46}$ In Peter Dews (ed.), Habermas: A Critical Reader, Oxford: Blackwell, 1999, 272- 290.
} 
use of language at all". Apel prefers to go by way of transcendental pragmatics, which "does not back away from the problem of an ultimate reflective justification of rationality". ${ }^{47}$

Apel's transcendental argument goes like this:

For let us imagine someone who did not wish to appeal to a rationality based on understanding concerning validity claims (in other words, their possible redemption or critique) at the level of the self-reflexive rationality of philosophical discourse, or who was unwilling to distinguish this type of rationality as the definitive form of human rationality. Such a person would find himself caught in a contradiction with the rationality of the discourse he is actually making use of: in other words, a performative self-contradiction. He would thereby show that every type of rationality which is appealed to as, or declared to be substitute for, the rationality of discourse is in fact parasitically dependent on discourse rationality. To this extent, Habermas's basic intuition - as outlined in The Theory of Communicative Action - can be salvaged. ${ }^{48}$

This argument depends on three claims of exclusivity:

(1) A philosophical theory is a privileged way of speaking about reason.

(2) Philosophical theories must be (a) rational and (b) discursive.

(3) Discursive rationality essentially fits Apel's description of it, i.e. it is "an argumentative discourse between parties who, in principle, have equal rights". ${ }^{49}$

So long as it is possible to produce an account of rationality that does not fit the description above, such an account would easily escape Apel's transcendental trap. Disqualifying such an account as 'irrational' or 'impossible to understand' would make the entire argument circular. One can still try to show such accounts to be parasitic upon the form of rationality advocated by Apel and Habermas using the good-old 'descriptive-empirical' method. This is what Habermas is trying to do, but I tend to agree with Apel here - to no avail.

It is possible to produce accounts of rationality that do not fit some of the exclusivity criteria above. Moreover, such accounts exist. What Derrida offers us in fact contains such an account. It is not argumentative, thus violating exclusivity claim ( $2 \mathrm{~b})$ above. It is this challenge to the argumentative form of human rationality that so enrages Habermas (cf. his comment on unsettling the institutionalized standards of fallibilism, quoted above). Habermas wishes to 'normalize' Derrida's work by all means, to replace it with something even excessively radical and subversive, but nevertheless argumentative.

After all, it is argumentative discourse that stands at the heart of Habermas's own solution to the aporias of modern philosophy - the theory of communicative action. The formalities of argument are deemed to rule all areas of human activity:

Communicative reason finds its criteria in the argumentative procedures for directly or indirectly redeeming claims to propositional truth, normative rightness and aesthetic harmony. ${ }^{50}$

This partition to propositional truth, normative rightness and aesthetic harmony is of course derived from Kant's pure reason, practical reason and judgment. As

\footnotetext{
47 Ibid., 275.

48 Ibid., 288- 289.

49 Ibid., 288.

50 PDM, 314.
} 
Christopher Norris points out, ${ }^{51}$ this Kantian division also stands at the basis of Habermas's Division of the Sciences at the end of the Excursus - his juxtaposition of literature, literary criticism, philosophy and the sciences, law, etc. in relation to everyday speech. "[I]n each of these enterprises," says Habermas, "the tools of rhetoric are subordinated to the discipline of a distinct form of argumentation". ${ }^{52}$

Now, this description is odd. If I were to steal someone's wallet, would I thus be making a validity claim to normative rightness? In some cases, perhaps, but most pickpockets care little about validity claims - they simply want the money. Perhaps Habermas did not refer to validity claims made by pickpockets, but rather to those made by lawyers and ethical theorists.

Still, what about literature? Habermas makes it quite clear, in the Excursus and elsewhere, that he views literature as a sphere of discourse, with its form of argumentation and its distinct kind of validity claims. Are we to suppose that novels, poems, plays, etc. make validity claims to aesthetic harmony? Well, we might find this element in some works, but surely making such validity claims is not the most important thing about works of literature. We would miss out next to everything about works of art and literature were we to examine them as simply making validity claims. Even such a friendly critic as J ames Bohman has to admit that:

Habermas's analogy between art and other culturally differentiated spheres of knowledge in modernity simply fails him here, since there are no specialized validity claims or forms of argumentation in art that correspond with the "function" of disclosure. It also seems difficult to isolate world disclosure as a distinct activity ... it is hard to know how "art and literature" are supposed to "administrate capacities for world-disclosure" in the same way that morality and science "administer problem-solving capacities". ${ }^{53}$

Making validity claims and arguing about them may be a reasonable description of literary criticism, but not of literature. In his eagerness to subordinate all discourse to argumentative discourse, Habermas collapses the very distinction between literature and literary criticism for which he so passionately argues in that very text. Moreover, since for Habermas fictional genres are merely subordinated to argumentative ones, he fails to recognize the actual difference between them. He views fiction as one more kind of argument, thus rendering the genre distinction between fiction and argument meaningless.

$* * *$

The tables have now turned. We saw that it is Habermas who is leveling the genre distinction between fiction and argument and it is Derrida who, in his own way, sustains it.

\section{References:}

Apel, Karl-Otto. “Openly Strategic Uses of Language: A Transcendental-Pragmatic

Perspective (A second attempt to think with Habermas against Habermas)". In Habermas:

A Critical Reader, edited by Peter Dews. Oxford: Blackwell, 1999.

Arieti, J ames A. Interpreting Plato: The Dialogs as Drama. Lanham, MD: Rowman \& Littlefield, 1991.

Beebee, Thomas. O. The Ideology of Genre: A Comparative Study of Generic Instability.

\footnotetext{
${ }^{51}$ Norris, “Deconstruction, Postmodernism, Philosophy,” 105.

52 PDM, 209- 210; italics added.

${ }^{53} \mathrm{~J}$ ames Bohman, "Two Versions of the Linguistic Turn: Habermas and Poststructuralism," in Habermas and the Unfinished Project of Modernity, 204.
} 
University Park: Pennsylvania State University Press, 1994.

Bernstein, J ay M. “The Causality of Fate: Modernity and Modernism in Habermas”. In Habermas and the Unfinished Project of Modernity, edited by Maurizio Passerin D’Entrèves and Seyla Benhabib. Cambridge: Polity Press, 1996.

Bohman, J ames. "Two Versions of the Linguistic Turn: Habermas and Poststructuralism". In Habermas and the Unfinished Project of Modernity, edited by Maurizio Passerin D'Entrèves and Seyla Benhabib. Cambridge: Polity Press, 1996.

Cohen, Ralph. "History and Genre". New Literary History. 17, no. 2 (1986): 203- 218.

Derrida, Jacques. “Différance”. In Margins of Philosophy, translated by Alan Bass. Brighton: The Harvester Press, 1982.

- - - "Envois". In The Post Card, translated by Alan Bass. Chicago: University of Chicago Press, 1987.

- - - "The Law of Genre," in Acts of Literature, edited by Derek Attridge. New York: Routledge, 1992.

- - . "White Mythology: Metaphor in the Text of Philosophy". In Margins of Philosophy, translated by Alan Bass. Brighton: The Harvester Press, 1982.

Fowler, Alastair. Kinds of Literature. Oxford: Clarendon Press, 1982.

Gasché, Rodolphe. Inventions of Difference: On J acques Derrida. Cambridge, MA: Harvard University Press, 1994.

Habermas, J ürgen. The Philosophical Discourse of Modernity: Twelve Lectures, translated by Frederick Lawrence. Cambridge MA: MIT Press, 1987.

Hoy, David Couzens. "Splitting the Difference: Habermas's Critique of Derrida". In Habermas and the Unfinished Project of Modernity, edited by Maurizio Passerin D’Entrèves and Seyla Benhabib. Cambridge: Polity Press, 1996.

McCarthy, Thomas. Introduction to The Philosophical Discourse of Modernity: Twelve Lectures, by J ürgen Habermas, translated by Frederick Lawrence. Cambridge MA: MIT Press, 1987.

Norris, Christopher. "Deconstruction, Postmodernism and Philosophy: Habermas on Derrida". In Habermas and the Unfinished Project of Modernity, edited by Maurizio Passerin D’Entrèves and Seyla Benhabib. Cambridge: Polity Press, 1996.

- - - . Derrida. Cambridge, MA: Harvard University Press, 1987.

- - - "Derrida on the Isles". Belgrade Circle J ournal 0 (1994). Also available online at http://www.usm.maine.edu/ bcj/issues/one/norris.html/.

Rorty, Richard. "Philosophy as a Kind of Writing: An Essay on Derrida". In Consequences of Pragmatism. Minneapolis: University of Minnesota Press, 1982.

Wood, David. "Style and Strategy at the Limits of Philosophy: Heidegger and Derrida". The Monist 63, no. 4 (1980): 494-511. 